\title{
A review of applications of poly(diallyldimethyl ammonium chloride) in polymer membrane fuel cells: From nanoparticles to support materials
}

\author{
Lei Du ${ }^{\mathrm{a}, \mathrm{b}}$, Fanpeng Kong ${ }^{\mathrm{b}}$, Guangyu Chen ${ }^{\mathrm{b}}$, Chunyu Du ${ }^{\mathrm{b}}$, Yunzhi Gao ${ }^{\mathrm{b}}$, Geping Yin a,b,* \\ a State Key Laboratory of Urban Water Resource and Environment, School of Chemistry and Chemical Engineering, Harbin Institute of Technology, Harbin \\ 150090, Heilongjiang, China \\ ${ }^{\mathrm{b}}$ Institute of Advanced Chemical Power Sources, School of Chemistry and Chemical Engineering, Harbin Institute of Technology, Harbin 150001, \\ Heilongjiang, China
}

\section{A R T I C L E I N F O}

Article history:

Received 11 March 2016

Accepted 26 April 2016

Published 5 July 2016

Keywords:

Polyelectrolyte

Nanoparticle

Support

Controllable synthesis

Functionalization

\begin{abstract}
A B S T R A C T
Polymer membrane fuel cells represent important sustainable energy devices because their operation involves zero emissions and low temperatures and their components exhibit low toxicity. Among the various components of such cells, the electrocatalyst plays the vital role of enhancing the output power density and/or working lifetime. Over the past several decades, numerous strategies have been proposed to address the challenges of electrocatalyst activity and/or durability. Herein, we review the applications of polyelectrolytes in electrocatalysts, including the enhancement of both catalytic nanoparticles and support materials. The effects of polyelectrolytes with regard to controlling the size, composition and morphology of catalytic nanoparticles, as well as the modification of support materials were summarized. In addition, the future possibilities for the research and development of polyelectrolytes in the field of catalyst design and synthesis are discussed.
\end{abstract}

(C) 2016, Dalian Institute of Chemical Physics, Chinese Academy of Sciences. Published by Elsevier B.V. All rights reserved.

\section{Introduction}

Polymer membrane fuel cells (PMFCs) are a promising means of addressing the present challenges of environmental pollution and energy shortages. Both anode and cathode electrocatalysts, typically composed of precious metals, are key components of PMFCs and play central roles in enhancing the output power density and extending the working lifetime [1-4]. It is notable that the performance of precious metal nanoparticles is limited primarily by several controllable parameters, including size distribution [5], composition [6-9] and morphology (a factor related to preferential facets) [10-13]. Each of these parameters is critical to the electrocatalysis process and significantly affects the reaction pathways and/or activities [14-19]. However, the size, composition and morphology of metal nanoparticles are difficult to tune during synthesis due to the nature of the precursors that are employed, and so various controlling agents, such as polymers and polyols, are often used. The as-prepared electrocatalysts also tend to suffer from agglomeration, dissolution, detachment of catalytic nanoparticles and, especially, severe corrosion of support materials during long-term operation [20-29]. As a result of these phenomena, PMFCs incorporating these materials may not meet the requirements for commercialization. At present, carbon materials such as 1D carbon nanotubes (CNTs) and fibers [30-38], 2D graphene [39-49] and 3D carbon [50-61] are still the most

\footnotetext{
* Corresponding author. Tel/Fax: +86-451-86403807; E-mail: yingeping@hit.edu.cn

This work is supported by the National Natural Science Foundation of China $(21276058,21433003)$ and the State Key Laboratory of Urban Water Resource and Environment (Harbin Institute of Technology) (2014DX10).

DOI: 10.1016/S1872-2067(16)62480-4 | http://www.sciencedirect.com/science/journal/18722067 | Chin. J. Catal., Vol. 37, No. 7, July 2016
} 
widely used supports due to their balanced performance, although they undergo more severe corrosion under fuel cell operating conditions [25-29,62-68] compared with other novel supports such as metal oxides [69-75] and metal carbides [76-82]. Graphitization is efficient at enhancing the stability of carbon materials, and can significantly reduce surface defects, although it also results in a decrease in the loading sites available for nanoparticles. Therefore, the development of catalytic nanoparticles (commonly precious metals and their alloys) exhibiting high activity and stability, as well as support materials with high stability, electrical conductivity and strong interactions with nanoparticles, is urgently required [3,83-93].

Polyelectrolytes have the potential to address the above challenges, and so are widely used in fabricating membrane electrode assembly (MEA) devices based on layer-by-layer self-assembly. Several excellent reviews of this subject have been published $[94,95]$ in addition to other reports regarding catalytic nanoparticles and/or support materials [96-105]. However, only minimal attention has been paid to the effects of polyelectrolytes with regard to tuning catalytic nanoparticles and functionalizing support materials. Herein, we focus on the applications of polyelectrolytes, particularly poly(diallyldimethyl ammonium chloride) (PDDA), in developing novel catalytic nanoparticles and carbon support materials with remarkably enhanced performance.

\section{Polyelectrolytes}

Polyelectrolytes, or polymeric electrolytes, are generally recognized as helpful agents in the design and synthesis of

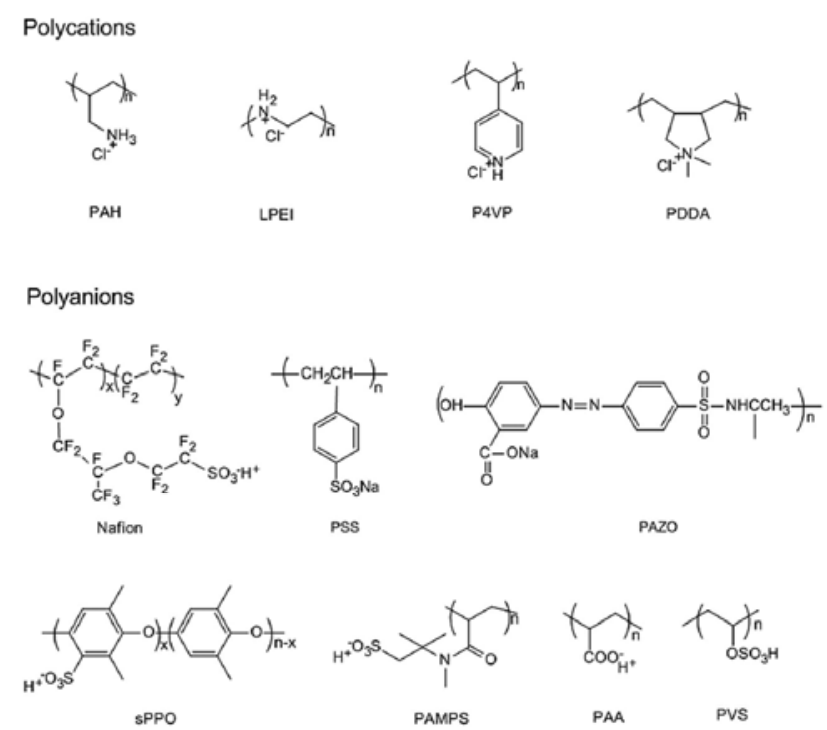

Fig. 1. Polycations: poly(allylamine hydrochloride) (PAH), linear poly(ethylene imine) (LPEI), poly(4-vinylpyridine) (P4VP), poly(diallyldimethyl ammonium chloride) (PDDA). Polyanions: Nafion, poly(sodium styrene sulfonate) (PSS), poly(1-(4-(3-carboxy-4-hydroxyphenylazo)benzene sulfonamido)-1,2-ethanediyl, sodium salt) (PAZO), sulfonated poly(2,6-dimethyl-1,4-phenylene oxide) (sPPO), poly(2acrylamido-2-methyl-1-propanesulfonic acid) (PAMPS), poly(acrylic acid) (PAA), poly(vinyl sulfate) (PVS). Reproduced with permission from Ref. [94]. Copyright (2012) Royal Society of Chemistry. electrocatalysts, due to their unique properties and/or charged states in aqueous solutions. Based on their charge states, polyelectrolytes can be classified as polycations, polyanions or polyampholytes, among which the polycations and polyanions are potentially useful in the field of PMFCs (Fig. 1) [94].

Polyelectrolytes in aqueous solution typically dissociate into long polymer chains and ions having opposite charges. Taking PDDA as an example, the polymer dissociates into $\mathrm{Cl}^{-}$ions and positively charged polymer chains (Fig. 2). Within the PDDA chains, the positively charged regions are hydrophilic amino groups, while the remainder of each chain is composed of hydrophobic hydrocarbyl regions (Fig. 2(a)). These charged polymer chains can form micelles, the shape and size of which depend on the concentration of the polymer. When the PDDA concentration is high, positively charged hydrophilic groups move outward to form a spherical micelle structure with exposed amino groups (Route I, Fig. 2(b)). At lower concentrations, the polymer chains will form a twisted structure (Route II, Fig. 2(c)) [106]. In addition, long chains with functional groups can adsorb on the surfaces of both catalytic nanoparticles and support materials, which is the basis for using polyelectrolytes to modify such materials. Interestingly, the modified nanoparticles and supports can be either positively or negatively charged by the polymer chains, depending on the polyelectrolyte type. Oppositely charged regions will tend to gather together based on electrostatic attraction, which leads to numerous possibilities with regard to synthesizing novel electrocatalysts and MEAs. The various uses of polyelectrolytes are all based on these unique properties.

It should be emphasized that most reports of polyelectrolyte in PMFCs are associated with layer-by-layer self-assembly, which involves non-covalent integration between two oppositely charged regions to produce highly ordered structures on the MEA level [94,95], rather than on the catalyst level. However, as researchers have developed a more profound understanding of polyelectrolytes, more and more investigations have focused on the application of polyelectrolytes to catalyst synthesis. Although the main object of our attention is PDDA at present, there is still much to be learned in this field regarding

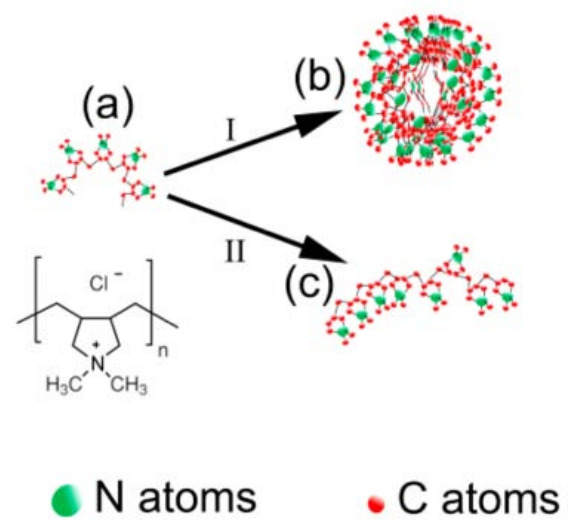

Fig. 2. Illustrations of a PDDA molecular chain and the PDDA monomer (a), the micelle structure at high PDDA concentrations (b), a twisted, long PDDA chain at low concentrations (c). Reproduced with permission from Ref. [106]. Copyright (2014) American Chemical Society. 
many other polyelectrolytes.

\section{Applications of polyelectrolytes to particle size control}

The size distribution of noble metal catalytic nanoparticles is crucial to electrocatalytic performance. Larger nanoparticles result in low specific surface areas and fewer potential active sites. However, smaller catalytic nanoparticles lead to poor durability because they typically agglomerate and dissolve more readily compared with larger particles. Thus, the appropriate size distribution represents a balance between the number of active sites and the durability of the electrocatalyst [107-109]. During metal nanoparticle synthesis, two successive steps can take place: nucleation and the growth of these nuclei. Commonly, increasing the nucleation rate and reducing the subsequent growth time will result in a smaller size distribution. This section discusses the function of polyelectrolytes in limiting the sizes of nanoparticles and in preventing degradation.

Taking Pt nanoparticles and PDDA as models, Fig. 3(a) depicts a possible reaction process for the formation of nanoparticles. The PDDA initially dissociates into long chains and $\mathrm{Cl}^{-}$ ions. Upon adding a Pt precursor such as chloroplatinic acid to the polymer solution, chloroplatinic ions $\left(\mathrm{PtCl}_{6}{ }^{2-}\right)$ replace the $\mathrm{Cl}^{-}$ions (that is, an ion-exchange process occurs) and are thus adsorbed on the PDDA chains at the N sites (step I, Fig. 3(a)) $[110,111]$. This process has been confirmed by UV-vis spectroscopy (Fig. 3(b)) [106]. Thus, the Pt precursor can be protected by a so-called "nanoreactor" consisting of PDDA chains. After introducing strong reductants such as ethanol or sodium borohydride, numerous Pt nuclei are rapidly formed (step II, Fig. 3(a)), after which these Pt seeds continue to grow while being restricted by the PDDA chains (step III, Fig. 3(a)). Thus, the Pt nanoparticle sizes can be controlled by the PDDA nanoreactor.

In early studies, several polyelectrolytes were investigated as stabilizers and control agents in the synthesis of Pt nanoparticles, applying a polyelectrolyte-to-Pt precursor molar ratio of $3: 1$, followed by reduction in ethanol/water ( $v: v=4: 6)$. The electrochemical characteristics of the resulting catalysts were then assessed in $1.0 \mathrm{~mol} / \mathrm{L} \mathrm{H}_{2} \mathrm{SO}_{4}+2.0 \mathrm{~mol} / \mathrm{L} \mathrm{CH}_{3} \mathrm{OH}$ or $\mathrm{O}_{2}$-saturated $1.0 \mathrm{~mol} / \mathrm{L} \mathrm{H}_{2} \mathrm{SO}_{4}$ solutions during the methanol oxidation reaction (MOR) and oxygen reduction reaction (ORR), respectively, with the results presented in Table 1 [111]. (a)
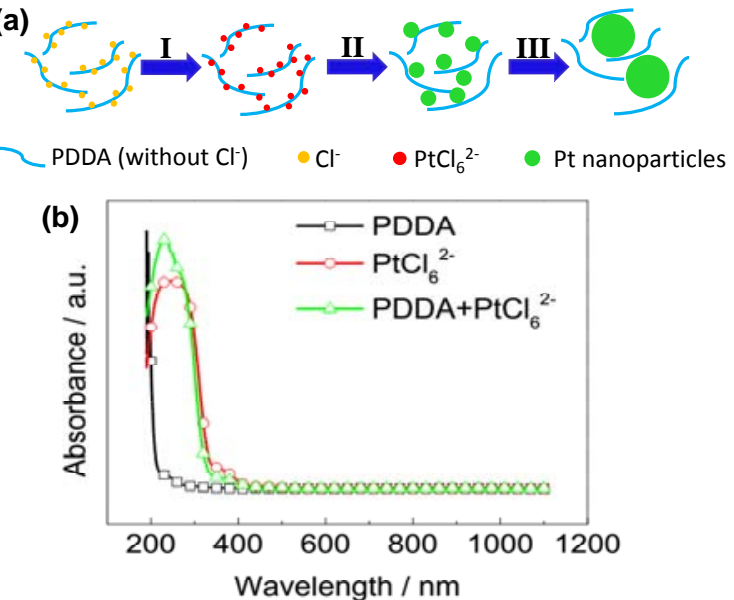

Fig. 3. (a) Illustration showing the growth of Pt nanoparticles in the presence of a polyelectrolyte; (b) UV-vis spectra of an aqueous PDDA solution, an aqueous $\mathrm{PtCl}_{6}{ }^{2-}$ solution and their mixture [106]. Copyright (2014) American Chemical Society.

From these data, it is evident that the size distribution of the $\mathrm{Pt}$ nanoparticles is well controlled in the range of 2 to $3 \mathrm{~nm}$, a range that is similar to that obtained with the widely used polyhydric alcohols method [112]. In addition, PDDA-Pt and PSS-Pt nanoparticles have been found to exhibit superior performance compared with commercial Pt black catalysts during both the MOR and ORR, indicating that both PDDA and PSS are potential size control agents for metal nanoparticles when using simple chemical reduction methods [110-114]. It is notable that the synthesis of Pt catalysts using other polyelectrolytes results in much lower activities, possibly due to significant adsorption on the Pt surfaces, blocking the active sites. Therefore, it is crucial to choose the most suitable polyelectrolyte, and the relationship between the polyelectrolyte and the catalyst performance requires further investigation. Because PDDA-Pt particles present the highest activity, it is helpful to focus on the effects of the PDDA-to-Pt precursor molar ratio on the size distribution. Studies have shown that a lower amount of PDDA (PDDA:Pt = 1:1) generates larger nanoparticles (approximately $4 \mathrm{~nm}$ in size) because the limiting effect of the nano-reactor is weakened [110]. However, greater amounts of PDDA can serve to block the active sites and lower the activity. Thus, the optimal PDDA:Pt molar ratio is in the range of 3:1 to 8:1.

As a means of stabilizing nanoparticles and thus synthesiz-

Table 1

Average particle sizes determined from transmission electron microscope (TEM) images, ECSA data acquired by cyclic voltammetry in 1.0 mol/L $\mathrm{H}_{2} \mathrm{SO}_{4}$, peak current density for the MOR in $1.0 \mathrm{~mol} / \mathrm{L} \mathrm{H}_{2} \mathrm{SO}_{4}+2.0 \mathrm{~mol} / \mathrm{L} \mathrm{CH}_{3} \mathrm{OH}(50 \mathrm{mV} / \mathrm{s})$ and current density at $0.5 \mathrm{~V}$ for the $0 \mathrm{RR}$ in $\mathrm{O}_{2}$-saturated 1.0 $\mathrm{mol} / \mathrm{L} \mathrm{H}_{2} \mathrm{SO}_{4}(5 \mathrm{mV} / \mathrm{s})$ at $2000 \mathrm{r} / \mathrm{min}$ for polyelectrolyte-stabilized Pt nanoparticles (NPs) and E-TEK Pt black. Reproduced with permission from Ref. [111]. Copyright (2007) Elsevier.

\begin{tabular}{lcccc}
\hline Pt NPs & Particle size $(\mathrm{nm})$ & ECSA $\left(\mathrm{m}^{2} / \mathrm{g}\right)$ & $\begin{array}{c}\text { Peak current density for MOR } \\
\text { @ 0.69 V }\left(\mathrm{mA} / \mathrm{cm}^{2}\right)\end{array}$ & $\begin{array}{c}\text { Current density for ORR @ 0.5 V }\left(\mathrm{mA} / \mathrm{cm}^{2}\right) \\
\text { @ 2000 r/min }\end{array}$ \\
\hline PDDA-Pt & $3.0 \pm 0.9$ & 13.6 & 7.5 & 1.25 \\
PSS-Pt & $2.7 \pm 0.4$ & 6.04 & 6.3 & 0.92 \\
Nafion-Pt & $2.4 \pm 0.4$ & 3.4 & 3.3 & 0.57 \\
PAMP-Pt & $2.2 \pm 0.5$ & 8.5 & 2.6 & 0.44 \\
PAA-Pt & $3.2 \pm 0.9$ & 9.68 & 1.5 & 0.18 \\
PAH-Pt & $2.4 \pm 0.4$ & Negligible & 0.4 & 0.02 \\
Pt black & $4.6 \pm 0.9$ & 11.8 & 5.5 & 0.71 \\
\hline
\end{tabular}


ing practical electrocatalysts, polyelectrolyte-assisted metal nanoparticles can be deposited on carbon materials by damaging the double layer using solutions that are strong acidic (such as $\mathrm{HNO}_{3}$ ), alkaline (such as $\mathrm{NaOH}$ ) or saline (such as $\mathrm{KNO}_{3}$ ), followed by stirring for a long period of time. Fig. 4(a) and (b) presents transmission electron microscope (TEM) images of a commercial Pt/C catalyst and well-dispersed PDDA-Pt nanoparticles loaded on Vulcan XC-72R carbon black by a method employing $\mathrm{NaOH}$. The mass-based activity (A/g) of PDDA-Pt/C has been shown to be approximately 1.45 times that of an Etek-Pt/C catalyst (Fig. 4(c)), which can be attributed to the well-defined size distribution as well as the $\mathrm{N}$-doping of the $\mathrm{Pt}$ nanoparticles [115]. Results such as these demonstrate novel strategies for developing doped materials that include metals [106] and carbon, as discussed in greater detail below. In fact, the use of a polyelectrolyte enhances not only the activity of the catalyst, but also the stability. As shown in Fig. 4(d) and (e), two accelerated degradation tests (ADTs) were applied to both the Etek-Pt/C and PDDA-Pt/C catalysts. The potential step trials, from $1.4 \mathrm{~V}$ for $10 \mathrm{~s}$ to $0.85 \mathrm{~V}$ for $5 \mathrm{~s}$ over $22 \mathrm{~h}$, would be expected to protect the Pt nanoparticles due to the passivation caused by the high potential, and thus allows efficient analysis of the corrosion of the carbon supports. In contrast, the potential cycling protocol allows one to assess the degradation of the Pt nanoparticles. From these data, it is evident that the use of PDDA effectively protects both the Pt nanoparticles and the underlying carbon support from degradation, an effect that is believed to result from protective layers formed by PDDA chains on the material surfaces.

Polyelectrolytes are also beneficial during the synthesis of alloys such as PtAu nanoparticles, which typically cannot be easily produced using polyhydric alcohols due to the reducibil- ity gap between the different precursors. This is the reason why polyhydric alcohols are typically used to synthesize Pt and $\mathrm{PtRu}$ alloys, but not to prepare PtAu alloys. Thus, the generation of uniform alloys from several metal precursors having different reducibilities must be performed using strong reductants such as sodium borohydride or hydrazine. The synthesis of overly large nanoparticles can be avoided during this process by employing a polyelectrolyte to tune the size of the PtAu alloy particles. Using this approach, PtAu nanoparticles approximately $3.1 \mathrm{~nm}$ in size with a high degree of alloying have been produced and loaded on graphene sheets [116]. Interestingly, the strong interaction between the PDDA and the graphene sheets [41] allows good dispersion of the PtAu nanoparticles supported by the graphene and also enhances durability during electrocatalysis [116].

\section{The application of polyelectrolytes to tuning nanocrystalline morphology}

In addition to size distribution, the unique structures of electrocatalysts (that is, their preferential facets) also play a central role in electrochemical reactions. The atomic arrangements of Pt and its alloys, as an example, can remarkably affect the atomic coordination number surrounding each Pt atom, which is an important parameter influencing the activity of the material towards specific electrochemical reactions [117-119]. Thus, the presence of the optimal facets can enhance electrochemical performance $[120,121]$. Pt nanocrystals are commonly synthesized with several low-index facets, including (111), (110) and (100), forming simple structures such as octahedrons, cubes and/or tetrahedra [122]. One of the earliest reports regarding the preparation of polydisperse Pt nano-
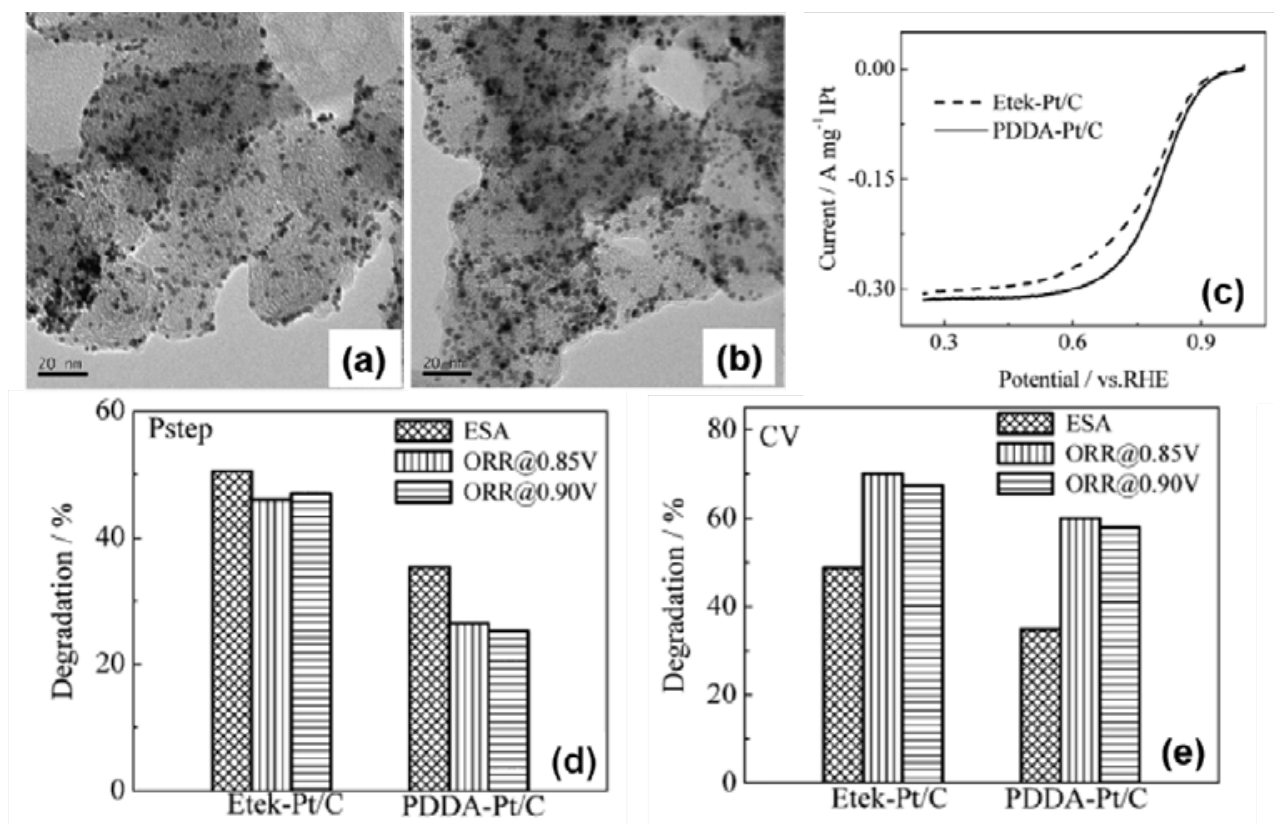

Fig. 4. TEM images of Etek Pt/C (a) and PDDA-Pt/C (b); (c) LSV data for Etek Pt/C and PDDA-Pt/C catalysts in oxygen-saturated 0.5 mol/L $\mathrm{H}_{2} \mathrm{SO}_{4}$ (10 $\mathrm{mV} / \mathrm{s}, 1600 \mathrm{r} / \mathrm{min}$ ); The degradation percentages of Etek Pt/C and PDDA-Pt/C catalysts after ADTs involving potential steps (1.4 to $0.85 \mathrm{~V}$ ) over $22 \mathrm{~h}$ (d) and potential cycling ( 0.6 to $1.1 \mathrm{~V}, 50 \mathrm{mV} / \mathrm{s}$ ) over 5000 cycles (e). Reproduced with permission from Ref. [115]. Copyright (2009) Royal Society of Chemistry. 
crystals, using PAAS as the controller, obtained nanocrystals consisting of a mixture of cubes and octahedra [123]. In subsequent studies, uniformly-dispersed Pt nanocrystals with optimal exposed facets were synthesized using simple capping agents, including macromolecules [31,124-129], various ions [128,130-133], metal carbonyls [134-139], traces of active metals [140,141] and/or electrochemical methods [119]. PDDA can also be employed for the purpose of controlling the morphology of Ag and Pd particles [114], to obtain shapes other than spherical. PDDA has been shown to allow the reduction of Pt precursors, as well as continuous tuning of the morphology of Pt nanocrystals from cubes to octahedra via a one-pot hydrothermal process [106]. The key factor in this control technique was found to be the PDDA concentration, with concentrations of 60,40 and $30 \mathrm{mg} / \mathrm{mL}$ generating cubes, truncated cubes and octahedra, respectively (Fig. 5(a)-(f)). The morphological control mechanism appears to be associated with the unique structures that PDDA chains assume at different concentrations, as shown in Fig. 2. As noted, concentrated PDDA trends to form spherical micelles with numerous exposed amino groups, which preferentially adsorb on and block the Pt (100) facets compared with the (111) facets (Fig. 5(g) and (h)). According to Bravis' law, the blocked Pt (100) facets lead to reduced growth rates and result in nanocrystals enclosed with (100) facets. Conversely, at low concentrations, the Pt nanocrystals are enclosed by (111) facets. This observation suggests that the application of PDDA to the synthesis of electrocatalysts can be extended to use as a reductant and a capping agent.

Another interesting example of the use of polyelectrolytes involves the preparation of binary or even ternary electrocatalysts with special morphologies via self-assembly, based on the unique charged properties of the polymer. In one process, $\mathrm{Pt}$ and Au colloids are positively and negatively charged, respectively, by the application of PDDA and citrate ions. After mixing these two colloids, the positively and negatively charged nanoparticles combine as the result of electrostatic attraction, leading to a unique Pt-around-Au catalyst (Fig. 6(a) and (b)), which exhibits remarkably enhanced activity towards formic acid oxidation [142]. This work not only provides a strategy for (a)
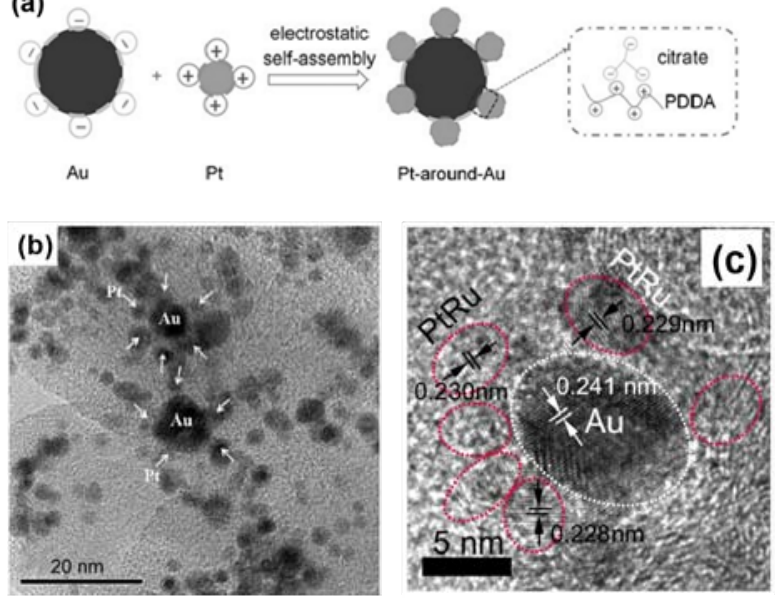

Fig. 6. (a) Illustration of the synthesis of a Pt-around-Au/C catalys; (b) TEM image of a Pt-around-Au/C catalyst. Reproduced with permission from Ref. [142]. Copyright (2010) John Wiley \& Sons, Inc. (c) TEM image of a PtRu-around-Au/C catalyst (unpublished image).

obtaining excellent electrocatalysts, but also reveals an efficient model for future investigations of reaction pathways due to the use of independent but connected Pt and Au nanoparticles. On this basis, our own group has developed a novel ternary PtRu-around-Au/C catalyst (Fig. 6(c)) intended for formic acid oxidation, which exhibits significantly enhanced performance.

As discussed above, polyelectrolytes can be used as nanoreactors to limit the growth of nanoparticles. This special confinement effect also leads to other possibilities regarding the preparation of catalysts with core-shell structures. In one such case, a film consisting of layers of PSS and PDDA is added into a $\mathrm{Au}$ precursor solution, following which the $\mathrm{AuCl}_{4}^{-}$anions tend to occupy the $\mathrm{Cl}^{-}$sites on the PDDA through an ion exchange process, and are subsequently reduced by sodium borohydride. An additional PSS layer is applied, followed by $\mathrm{Ag}^{+}$cation exchange and reduction, leading to the formation of $\mathrm{Au} @ \mathrm{Ag}$ core-shell nanoparticles (Fig. 7(a)) [143]. Fig. 7(b)-(d) show the energy-dispersive X-ray (EDX) elemental maps of $\mathrm{Au}$ and Ag obtained from this electrocatalyst, confirming the
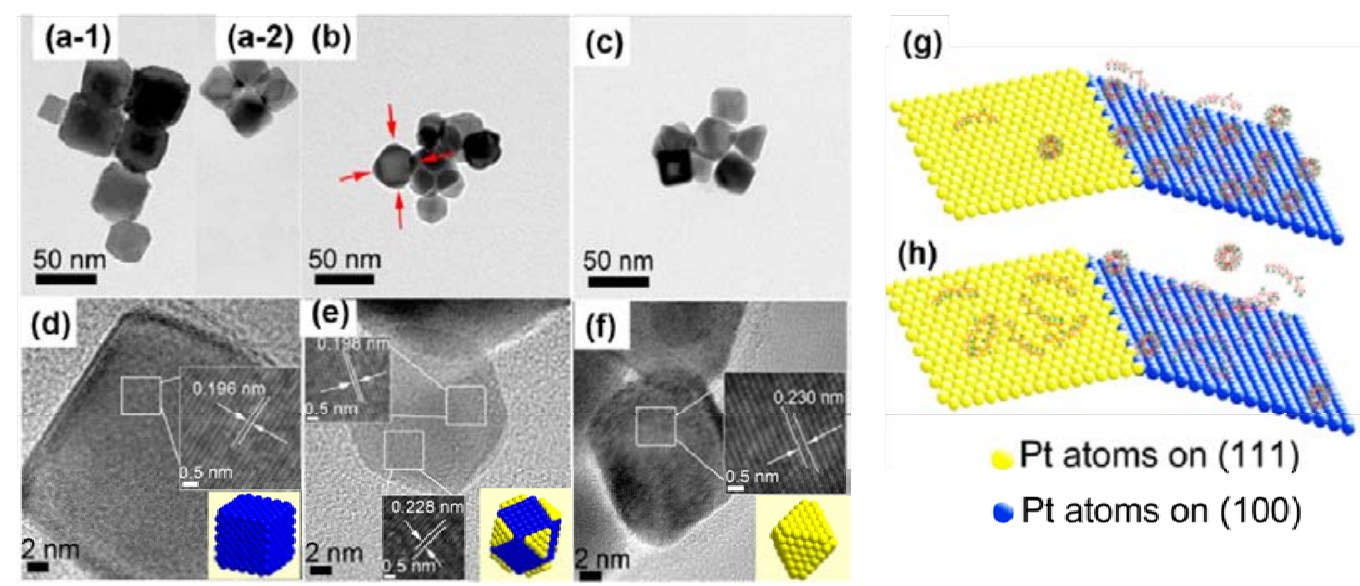

Fig. 5. Representative TEM images of Pt cubes (a), truncated cubes (b), and octahedrons (c). Representative HRTEM images of cubes (d), truncated cubes (e), and octahedrons (f). (g, h) Illustrations of PDDA adsorbed on different facets. Reproduced with permission from Ref. [106]. Copyritht (2014 American Chemical Society. 

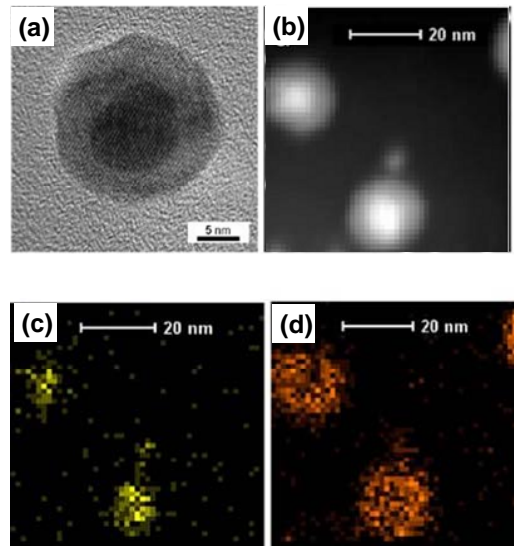

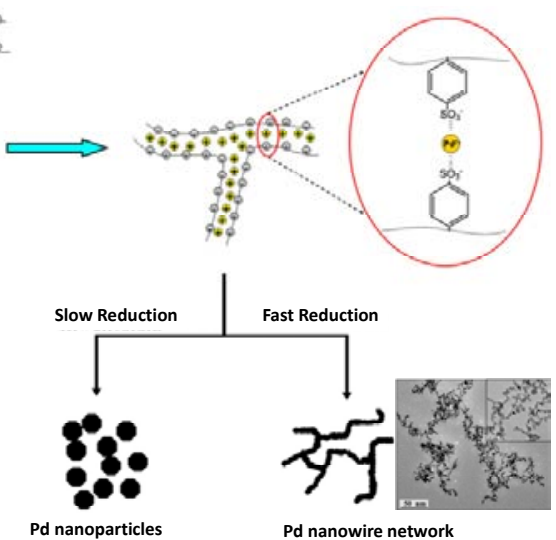

Fig. 7. (a) HRTEM image of a Au-Ag bimetallic NP; (b) HADDF-STEM image of Au-Ag bimetallic NPs. EDX elemental maps of Au (c) and Ag (d) corresponding to image (b). Reproduced with permission from Ref. [143]. Copyright (2012) American Chemical Society. (e) An illustration of the templateless and PSS-mediated self-assembly of Pd nanowire networks and NPs. Reproduced with permission from Ref. [144]. Copyright (2008) IOP Publishing.

well-defined Au core-Ag shell structure with uniform sizes. The formation of PSS networks in aqueous solutions can also be used to control the assembly of $\mathrm{Pd}^{2+}$ ions via the suspended sulfo groups of the polymer. The reduction rate of the Pd ions can be controlled such that the ions form particles having various morphologies (Fig. 7(e)). These observations demonstrate that nanocrystals with unique morphologies can be designed by utilizing the special properties of polyelectrolytes.

Although the polyelectrolyte-assisted methods show significant potential with regard to catalyst synthesis, a challenge that should not be neglected is the blocked active sites that result from adsorbed polyelectrolytes; these absorbed polymers are difficult to completely remove solely by washing with water or ethanol. Among several possible solutions to this problem, annealing has been found to give the best results [145], although the associated high temperatures may induce agglomeration of metal nanoparticles, thus lowering the electrochemical surface area. One possible means of mitigating this agglomeration is to protect the metal nanoparticles with highly heat stable compounds that are easily removed after synthesis, such as MgO [146]. However, other efficient strategies to prevent heat-induced agglomeration are still required.

\section{The role of polyelectrolytes as noncovalent functionalizing supports}

As discussed in the Introduction, the commonly employed carbon-based support materials are not completely satisfactory because they can undergo severe corrosion during the fuel cell operation [100]. A possible method to enhance the stability of typical carbon materials is graphitization, even though this can reduce the sites available for nanoparticles loading. As an alternative, non-covalent polyelectrolyte functionalization has shown potential $[35,36,93,147]$. As can be seen from Fig. 8(a), the PDDA is able to adsorb onto and non-covalently functionalize graphited CNTs. The polymer chains also electrostatically attract the $\mathrm{PtCl}_{6}{ }^{2-}$ precursor ions, resulting in a PDDA-bridged composite composed of Pt and a carbon support that is much more stable than standard Pt/CNT catalysts [35,147]. TEM images of both Pt/CNT and Pt/PDDA-CNT catalysts before and after an ADT using a potential step protocol (1.4 to $0.85 \mathrm{~V}$ ) are presented in Fig. 8(b)-(e). The Pt/PDDA-CNT exhibits a uniformly well-defined $\mathrm{Pt}$ nanoparticle dispersion (Fig. 8(c)) compared with the Pt/CNT (Fig. 8(b)). In the absence of the
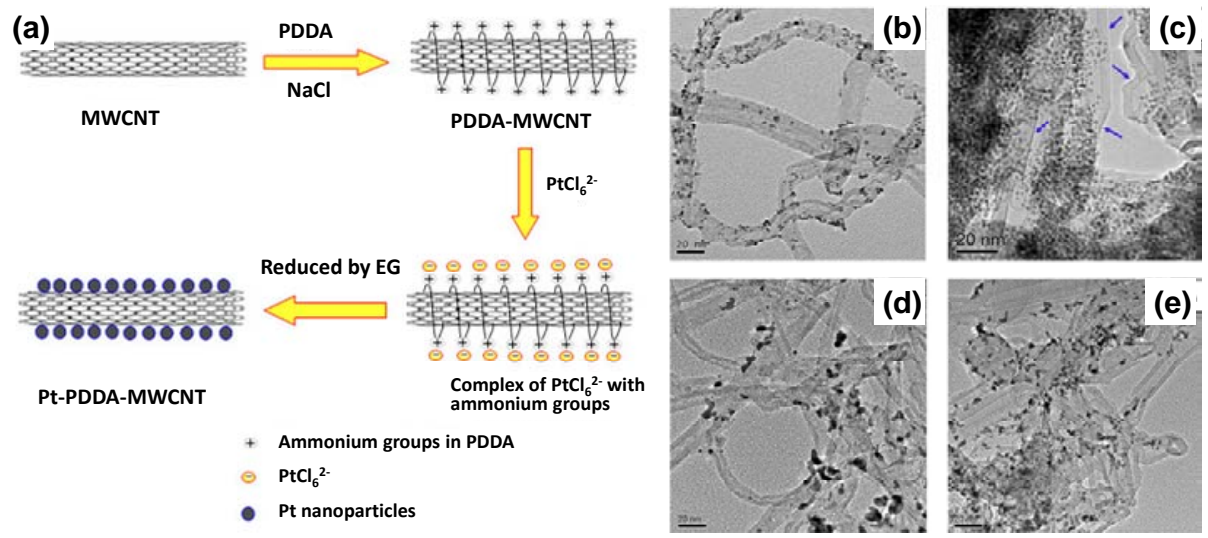

Fig. 8. (a) Illustration of the Pt/PDDA-CNT synthesis process. Reproduced with permission from Ref. [147]. Copyright (2008) IOP Publishing. Typical TEM images of fresh Pt/CNT (b) and Pt/PDDA-GCNT (c), and Pt/CNT (d) and Pt/PDDA-GCNT (e) catalysts following an ADT employing a potential step protocol (1.4 to 0.85 V). Reproduced with permission from Ref. [35]. Copyright (2010) Elsevier. 
PDDA, the Pt nanoparticles are seen to undergo severe agglomeration on the CNTs, with significant particle size growth (Fig. 8(b) and (d)). In contrast, the Pt nanoparticles on the PDDA-CNT retain their original sizes (Fig. 8(c) and (e)), which can be attributed to the anchoring effect of the PDDA on the CNT surfaces [35,148-152]. PAH [36], CTAB [153-155] and PSS [31] have also shown the ability to modify carbon supports in this manner.

Another useful study focused on modifying graphene with PVP followed by the deposition of reduced Pd seeds and the fabrication of Pt nanobranches through reduction by ascorbic acid to form 3D Pt-on-Pd electrocatalysts supported on graphene (Fig. 9(a)) [156]. Fig. 9(b) and (c) presents TEM images of this 3D Pt-on-Pd/graphene catalyst that demonstrate the uniformly well-defined structure in which Pt branches are situated on Pd seeds (Fig. 9(d) and (e)). These materials showed significantly enhanced electrochemical surface areas and correspondingly higher activity towards methanol oxidation. Although this work employed PVP rather than a true polyelectrolyte, it can be expected that polyelectrolytes also have the potential to assist in preparing multi-component catalysts with particularly well-defined structures, given that polyelectrolytes have been successfully used in modifying graphene [41,157]. What should be emphasized is that PDDA can be used as a reductant when preparing graphene from graphite oxide in aqueous solutions, because the $\mathrm{N}^{+}$groups in PDDA can interact with the epoxides on the graphite oxide [41]. Thus, the PDDA may also be used as a doping agent to synthesize N-doped carbon materials. N-doped, PDDA-functionalized CNTs [158] and graphene [159] could be applied to the catalysis of the ORR as non-precious metal catalysts. As an example, PDDA-CNT presents significantly improved ORR activity very close to that obtained from a Pt/C catalyst in alkaline solutions (Fig. 10(a)) [158]. This can be attributed to the electron-withdrawing ability of the $\mathrm{N}^{+}$group in the PDDA, which results in intermolecular charge transfer and forms delocalized positive charges on the conjugated carbon surfaces. This strategy tunes the electronic properties and adsorption ability of graphene for oxygen molecules to a remarkable extent (Fig. 10(b)) [158,159]. In addition, PDDA-carbon materials exhibit much higher stability un-
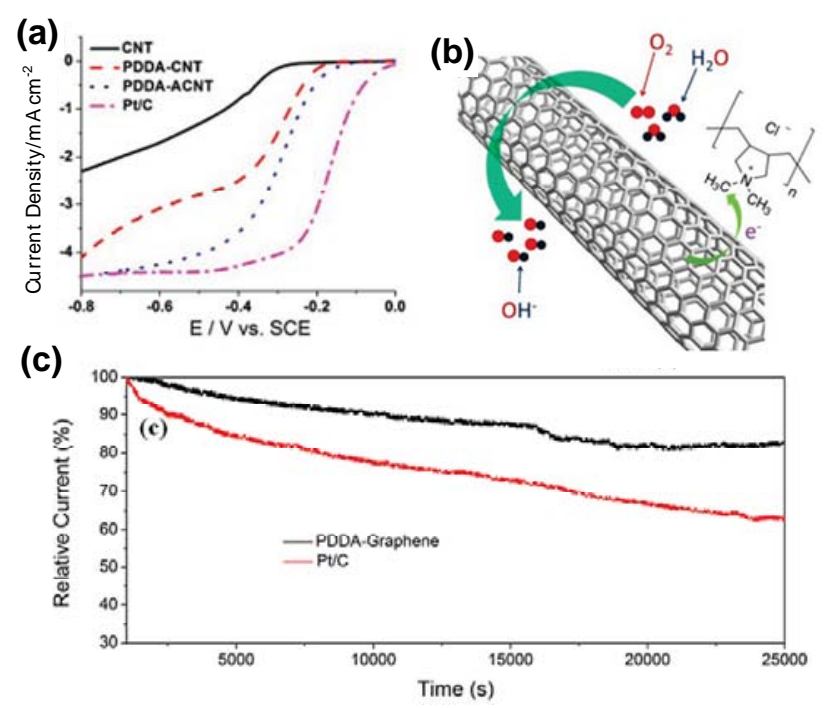

Fig. 10. (a) LSV data acquired during the $O R R$ in an $\mathrm{O}_{2}$-saturated 0.1 $\mathrm{mol} / \mathrm{L} \mathrm{KOH}$ solution at a scan rate of $10 \mathrm{mV} / \mathrm{s}$ and a rotation rate of $1600 \mathrm{r} / \mathrm{min}$. (b) Illustration of the charge transfer process and oxygen reduction reaction on a PDDA-CNT catalyst. Reproduced with permission from Ref. [158]. Copyright (2011) American Chemical Society. (c) The current-time $(i-t)$ chronoamperometric responses during the ORR at PDDA-graphene and $\mathrm{Pt} / \mathrm{C}$ electrodes in an $\mathrm{O}_{2}$-saturated $0.1 \mathrm{~mol} / \mathrm{L}$ $\mathrm{KOH}$ solution at $-0.28 \mathrm{~V}$ versus SCE at a rotation rate of $1000 \mathrm{r} / \mathrm{min}$. Reproduced with permission from Ref. [159]. Copyright (2011) American Chemical Society.

der typical reaction conditions compared with Pt/C (Fig. 10(c)) [158].

The above results show that polyelectrolytes can be used as bridges between nanoparticles and supports, leading to strong interactions between these two components. Additionally, it is notable that polyelectrolyte-modified Pt nanoparticles can be directly fabricated in place on polymeric membrane surfaces [160]. In this case, the polyelectrolyte can also be used to modify the membrane, leading to better stability and low organic crossover [161-163]. Such reports indicate that polyelectrolytes can most likely serve to bridge the catalyst, membrane and diffusion layers in an MEA, which could be beneficial with regard to integrating catalyst synthesis and MEA fabrication.
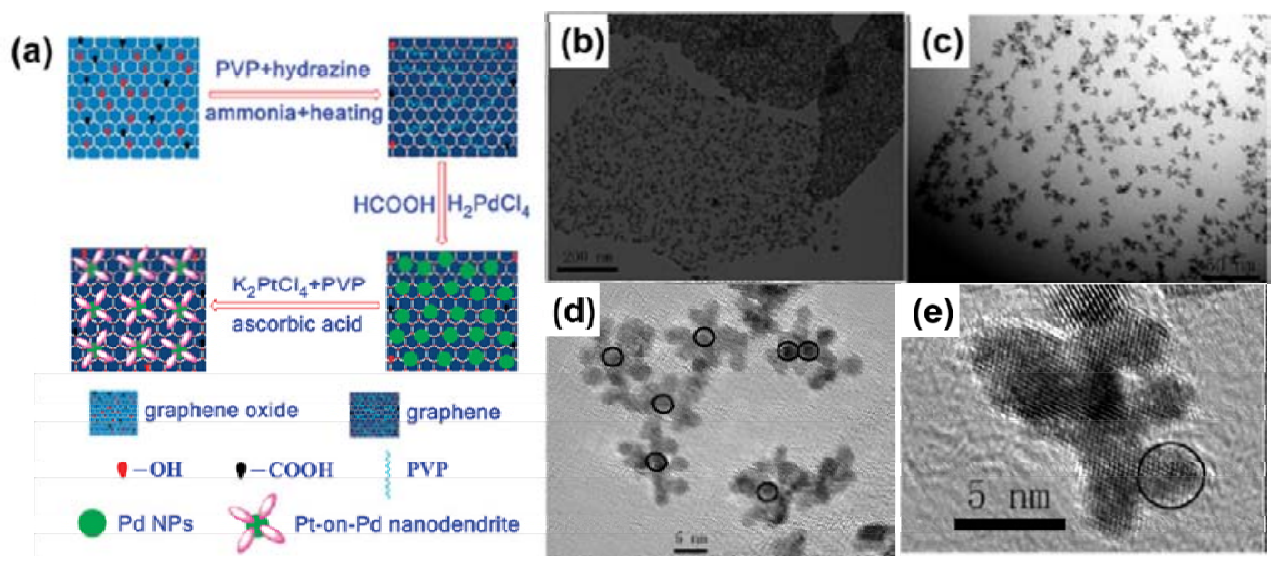

Fig. 9. (a) Procedure used to fabricate graphene nanosheet/Pt-on-Pd bimetallic nanodendrite hybrids. TEM (b,c) and HRTEM (d,e) images of 3D Pt-on-Pd bimetallic nanodendrites supported on graphene nanosheets, acquired at different magnifications. The circled region in panel (d) denote Pd NPs. Reproduced with permission from Ref. [156]. Copyritht (2010) American Chemical Society. 


\section{Summary and perspective}

Electrocatalysts play critical roles in energy conversion devices. Although the application of polyelectrolytes to the fabrication of MEAs via layer-by-layer self-assembly has been investigated for many years $[94,95]$, the role of polyelectrolytes in catalyst synthesis requires further attention. Recently, many electrolytes have been applied to catalyst synthesis, including LPEI [164-166], P4VP [167], PAA [168-171], PSS [172-180], PVS [181], sPPO [182] and PDDA (Fig. 1), among which PDDA has been investigated in significant detail. Therefore, this review focused on PDDA and aimed to summarize the currently-available information as well as to provide a more general perspective regarding the research and development of polyelectrolytes in the field of catalysts synthesis.

Polyelectrolyte have three useful properties; (1) they readily dissociate into oppositely charged chains and ions in aqueous solutions, (2) they can contain unique functional groups, and (3) they can undergo structural transformations with changes in solution concentration. Thus, polyelectrolytes can act as nanoreactors to control the growth of metal nanoparticles, to functionalize or dope nanoparticles or support materials, to protect nanoparticles and supports from degradation, and/or to charge other components to prepare ordered catalysts by self-assembly. However, the majority of studies to date have been based on PDDA and so it would be beneficial to systematically investigate other polyelectrolytes to better understand the relationships between the various parameters of polyelectrolytes, catalysts and electrocatalytic performance.

Although various reports have described applications of PDDA, there are still some issues that should be addressed in future investigations. Firstly, polyelectrolytes typically present poor electrical conductivity, which will affect the activity of catalysts upon blocking of active sites. Despite various proposed strategies, such as annealing, washing with chemicals and/or photodegradation to remove residual polyelectrolyte, systematic studies are still needed. Secondly, advanced tools (such as in situ characterizations and simulations) need to be developed, particularly to develop an understanding of the functions or effects of polyelectrolytes during catalyst formation in terms of the structure-property relationship. Finally, catalysts are commonly evaluated in half-cell or three-electrode systems that are completely different from actual fuel cell devices, such as MEAs. Due to their complex working conditions, including heat and water management and interfaces between components, MEAs using polyelectrolyte-assisted catalysts will likely exhibit undesirable levels of performance. Thus, the processing of MEA materials and the fabrication of the devices themselves may need to be revisited if polyelectrolytes are involved in the synthesis process.

\section{Acknowledgments}

L. Du acknowledges a scholarship from the China Scholarship Council.

\section{References}

[1] A. Z. Weber, J. Newman, Chem. Rev., 2004, 104, 4679-4726.

[2] M. Winter, R. J. Brodd, Chem. Rev., 2004, 104, 4245-4270.

[3] M. K. Debe, Nature, 2012, 486, 43-51.

[4] H. A. Gasteiger, N. M. Markovic, Science, 2009, 324, 48-49.

[5] O. V. Cherstiouk, P. A. Simonov, E. R. Savinova, Electrochim. Acta, 2003, 48, 3851-3860.

[6] D. Friebel, V. Viswanathan, D. J. Miller, T. Anniyev, H. Ogasawara, A. H. Larsen, C. P. O'Grady, J. K. Norskov, A. Nilsson, J. Am. Chem. Soc., 2012, 134, 9664-9671.

[7] C. Baldizzone, L. Gan, N. Hodnik, G. P. Keeley, A. Kostka, M. Heggen, P. Strasser, K. J. J. Mayrhofer, ACS Catal., 2015, 5, 5000-5007.

[8] S. I. Choi, S. U. Lee, W. Y. Kim, R. Choi, K. Hong, K. M. Nam, S. W. Han, J. T. Park, ACS Appl. Mater. Interfaces, 2012, 4, 6228-6234.

[9] S. I. Choi, S. F. Xie, M. H. Shao, J. H. Odell, N. Lu, H. C. Peng, L. Protsailo, S. Guerrero, J. Park, X. H. Xia, J. G. Wang, M. J. Kim, Y. Xia, Nano Lett., 2013, 13, 3420-3425.

[10] C. Wang, N. M. Markovic, V. R. Stamenkovic, ACS Catal., 2012, 2, 891-898.

[11] S. J. Guo, D. G. Li, H. Y. Zhu, S. Zhang, N. M. Markovic, V. R. Stamenkovic, S. H. Sun, Angew. Chem. Int. Ed., 2013, 52, 3465-3468.

[12] Y. Kang, X. Ye, J. Chen, Y. Cai, R. E. Diaz, R. R. Adzic, E. A. Stach, C. B. Murray, J. Am. Chem. Soc., 2013, 135, 42-45.

\section{Graphical Abstract}

Chin. J. Catal., 2016, 37: 1025-1036 doi: 10.1016/S1872-2067(16)62480-4

\section{A review of applications of poly(diallyldimethyl ammonium chloride) in polymer membrane fuel cells: From nanoparticles to support materials}

Lei Du, Fanpeng Kong, Guangyu Chen, Chunyu Du, Yunzhi Gao, Geping Yin*

Harbin Institute of Technology

Electrocatalysts are important materials in energy conversion systems. This article reviews the applications of polyelectrolytes in catalyst design and synthesis, including nanoparticle tuning and support functionalization.




[13] C. Koenigsmann, A. C. Santulli, K. Gong, M. B. Vukmirovic, W. P. Zhou, E. Sutter, S. S. Wong, R. R. Adzic, J. Am. Chem. Soc., 2011, 133, 9783-9795.

[14] C. Wang, D. van der Vilet, K. C. Chang, H. You, D. Strmcnik, J. A. Schlueter, N. M. Markovic, V. R. Stamenkovic, J. Phys. Chem. C, 2009, 113, 19365-19368.

[15] M. Nesselberger, M. Roefzaad, R. Faycal Hamou, P. Ulrich Biedermann, F. F. Schweinberger, S. Kunz, K. Schloegl, G. K. H. Wiberg, S. Ashton, U. Heiz, K. J. J. Mayrhofer, M. Arenz, Nat. Mater., 2013, 12, 919-924.

[16] V. R. Stamenkovic, B. S. Mun, M. Arenz, K. J. J. Mayrhofer, C. A. Lucas, G. F. Wang, P. N. Ross, N. M. Markovic, Nat. Mater., 2007, 6, 241-247.

[17] M. H. Shao, G. N. He, A. Peles, J. H. Odell, J. Zeng, D. Su, J. Tao, T. Yu, Y. M. Zhu, Y. N. Xia, Chem. Commun., 2013, 49, 9030-9032.

[18] X. Q. Huang, Z. P. Zhao, L. Cao, Y. Chen, E. B. Zhu, Z. Y. Lin, M. F. Li, A. M. Yan, A. Zettl, Y. M. Wang, X. F. Duan, T. Mueller, Y. Huang, Science, 2015, 348, 1230-1234.

[19] W. J. Zhou, M. Li, O. L. Ding, S. H. Chan, L. Zhang, Y. H. Xue, Int. J. Hydrogen Energy, 2014, 39, 6433-6442.

[20] Y. Y. Shao, G. P. Yin, Y. Z. Gao, P. F. Shi, J. Electrochem. Soc., 2006, 153, A1093-A1097.

[21] Y. Y. Shao, G. P. Yin, Y. Z. Gao, J. Power Sources, 2007, 171, 558-566.

[22] M. C. Smith, J. A. Gilbert, J. R. Mawdsley, S. Seifert, D. J. Myers, J. Am. Chem. Soc., 2008, 130, 8112-8113.

[23] P. Trogadas, J. Parrondo, F. Mijangos, V. Ramani, J. Mater. Chem., 2011, 21, 19381-19388.

[24] M. P. Rodgers, L. J. Bonville, R. Mukundan, R. Borup, R. Ahluwalia, P. Beattie, R. P. Brooker, N. Mohajeri, H. R. Kunz, D. K. Slattery, J. M. Fenton, ECS Trans., 2013, 58, 129-148.

[25] K. J. J. Mayrhofer, S. J. Ashton, J. C. Meier, G. K. H. Wiberg, M. Hanzlik, M. Arenz, J. Power Sources, 2008, 185, 734-739.

[26] K. Hartl, M. Hanzlik, M. Arenz, Energy Environ. Sci., 2011, 4, 234-238.

[27] J. C. Meier, C. Galeano, I. Katsounaros, A. A. Topalov, A. Kostka, F. Schüth, K. J. J. Mayrhofer, ACS Catal., 2012, 2, 832-843.

[28] J. C. Meier, I. Katsounaros, C. Galeano, H. J. Bongard, A. A. Topalov, A. Kostka, A. Karschin, F. Schüth, K. J. J. Mayrhofer, Energy Environ. Sci., 2012, 5, 9319-9330.

[29] K. Yu, D. J. Groom, X. P. Wang, Z. W. Yang, M. Gummalla, S. C. Ball, D. J. Myers, P. J. Ferreira, Chem. Mater., 2014, 26, 5540-5548.

[30] Y. Y. Shao, G. P. Yin, J. J. Wang, Y. Z. Gao, P. F. Shi, J. Power Sources, 2006, 161, 47-53.

[31] W. Yang, X. L. Wang, F. Yang, C. Yang, X. R. Yang, Adv. Mater., 2008, 20, 2579-2587.

[32] S. W. Lee, B. S. Kim, S. Chen, Y. Shao-Horn, P. T. Hammond, J. Am. Chem. Soc., 2009, 131, 671-679.

[33] L. Hu, D. S. Hecht, G. Gruner, Chem. Rev., 2010, 110, 5790-5844.

[34] W. Xiong, F. Du, Y. Liu, A. Perez Jr., M. Supp, T. S. Ramakrishnan, L. M. Dai, L. Jiang, J. Am. Chem. Soc., 2010, 132, 15839-15841.

[35] S. Zhang, Y. Y. Shao, G. P. Yin, Y. H. Lin, Appl. Catal. B, 2011, 102, 372-377.

[36] S. Zhang, Y. Y. Shao, G. P. Yin, Y. H. Lin, J. Mater. Chem., 2010, 20, 2826-2830.

[37] T. Shu, S. J. Liao, C. T. Hsieh, A. K. Roy, Y. Y. Liu, D. Y. Tzou, W. Y. Chen, Electrochim. Acta, 2012, 75, 101-107.

[38] Z. H. Yang, M. R. Berber, N. Nakashima, Electrochim. Acta, 2015, $170,1-8$.

[39] K. Parvez, S. B. Yang, Y. Hernandez, A. Winter, A. Turchanin, X. L. Feng, K. Mullen, ACS Nano, 2012, 6, 9541-9550.

[40] S. J. Guo, S. H. Sun, J. Am. Chem. Soc., 2012, 134, 2492-2495.
[41] S. Zhang, Y. Y. Shao, H. G. Liao, M. H. Engelhard, G. P. Yin, Y. H. Lin, ACS Nano, 2011, 5, 1785-1791.

[42] J. Balamurugan, T. D. Tran, N. H. Kim, J. H. Lee, Adv. Mater. Interfaces, 2016, 3, 1500348(1-10).

[43] M. Govindhan, B. Mao, A. Chen, Nanoscale, 2016, 8, 1485-1492.

[44] M. A. Hoque, F. M. Hassan, D. Higgins, J. Y. Choi, M. Pritzker, S. Knights, S. Ye, Z. W. Chen, Adv. Mater., 2015, 27, 1229-1234.

[45] C. T. Hsieh, P. Y. Yu, D. Y. Tzou, J. P. Hsu, Y. R. Chiu, J. Electroanal. Chem., 2016, 761, 28-36.

[46] H. J. Huang, S. B. Yang, R. Vajtai, X. Wang, P. M. Ajayan, Adv. Mater., 2014, 26, 5160-5165.

[47] X. C. Qiao, S. J. Liao, G. H. Wang, R. P. Zheng, H. Y. Song, X. H. Li, Carbon, 2016, 99, 272-279.

[48] Y. C. Qin, X. Zhang, X. P. Dai, H. Sun, Y. Yang, X. S. Li, Q. X. Shi, D. W. Gao, H. Wang, N. F. Yu, S.G. Sun, Small, 2016, 12, 524-533.

[49] G. Zhang, W. T. Lu, F. F. Cao, Z. D. Xiao, X. S. Zheng, J. Power Sources, 2016, 302, 114-125.

[50] Z. H. Yang, I. Moriguchi, N. Nakashima, ACS Appl. Mater. Interfaces, 2015, 7, 9800-9806.

[51] B. Z. Fang, J. H. Kim, C. Lee, J. S. Yu, J. Phys. Chem. C, 2008, 112, 639-645.

[52] C. Baldizzone, S. Mezzavilla, H. W. P. Carvalho, J. C. Meier, A. K. Schuppert, M. Heggen, C. Galeano, J. D. Grunwaldt, F. Schuth, K. J. J. Mayrhofer, Angew. Chem. Int. Ed., 2014, 53, 14250-14254.

[53] F. Hasché, T. P. Fellinger, M. Oezaslan, J. P. Paraknowitsch, M. Antonietti, P. Strasser, ChemCatChem, 2012, 4, 479-483.

[54] Y. J. Li, Y. J. Li, E. B. Zhu, T. McLouth, C. Y. Chiu, X. Q. Huang, Y. Huang, J. Am. Chem. Soc., 2012, 134, 12326-12329.

[55] S. Park, Y. Shao, H. Wan, P. C. Rieke, V. V. Viswanathan, S. A. Towne, L. V. Saraf, J. Liu, Y. Lin, Y. Wang, Electrochem. Commun., 2011, 13, 258-261.

[56] D. P. He, K. Cheng, T. Peng, M. Pan, S. C. Mu, J. Mater. Chem. A, 2013, 1, 2126-2132.

[57] P. Ramesh, M. E. Itkis, J. M. Tang, R. C. Haddon, J. Phys. Chem. C, 2008, 112, 9089-9094.

[58] R. W. Chen, J. Yan, Y. Liu, J. H. Li, J. Phys. Chem. C, 2015, 119, 8032-8037.

[59] S. L. Zhao, H. J. Yin, L. Du, G. P. Yin, Z. Y. Tang, S. Q. Liu, J. Mater. Chem. A, 2014, 2, 3719-3724.

[60] S. H. Joo, S. J. Choi, I. Oh, J. Kwak, Z. Liu, O. Terasaki, R. Ryoo, Nature, 2001, 412, 169-172.

[61] B. Z. Fang, J. H. Kim, M. Kim, J. S. Yu, Chem. Mater., 2009, 21, 789-796.

[62] J. Parrondo, T. Han, E. Niangar, C. M. Wang, N. Dale, K. Adjemian, V. Ramani, Proc. Natl. Acad. Sci. USA, 2014, 111, 45-50.

[63] C. A. Reiser, L. Bregoli, T. W. Patterson, J. S. Yi, J. D. Yang, M. L. Perry, T. D. Jarvi, Electrochem. Solid-State Lett., 2005, 8, A273-A276

[64] A. A. Franco, M. Guinard, B. Barthe, O. Lemaire, Electrochim. Acta, 2009, 54, 5267-5279.

[65] P. T. Yu, W. Gu, R. Makharia, F. T. Wagner, H. A. Gasteiger, ECS Trans., 2006, 3, 797-809.

[66] R. Borup, DOE 2014 Annual Merit Review Meeting, 2014, https://www.hydrogen.energy.gov/pdfs/review14/fc013_borup_ 2014_o.pdf.

[67] K. L. More, DOE 2013 Annual Merit Review Meeting, 2013, https://www.hydrogen.energy.gov/pdfs/review13/fc020_more_ 2013_o.pdf.

[68] K. L. More, DOE 2014 Annual Merit Review Meeting, 2014, https://www.hydrogen.energy.gov/pdfs/review14/fc020_more_ 2014_o.pdf.

[69] A. Altamirano-Gutierrez, A. M. Fernandez, F. J. R. Varela, Int. J. Hydrogen Energy, 2013, 38, 12657-12666. 
[70] Y. G. Chen, J. J. Wang, X. B. Meng, Y. Zhong, R. Y. Li, X. L. Sun, S. Y. Ye, S. Knights, Int. J. Hydrogen Energy, 2011, 36, 11085-11092.

[71] M. L. Dou, M. Hou, Z. L. Li, F. Wang, D. Liang, Z. G. Shao, B. L. Yi, J. Energy Chem., 2015, 24, 39-44.

[72] M. L. Hernandez-Pichardo, R. G. Gonzalez-Huerta, P. del Angel, M. Tufino-Velazquez, L. Lartundo, Int. J. Hydrogen Energy, 2015, 40, 17371-17379.

[73] A. Ignaszak, C. Teo, S. Y. Ye, E. Gyenge, J. Phys. Chem. C, 2010, 114, 16488-16504.

[74] D. H. Lim, W. D. Lee, D. H. Choi, H. H. Kwon, H. I. Lee, Electrochem. Commun., 2008, 10, 592-596.

[75] M. Yin, J. Y. Xu, Q. F. Li, J. O. Jensen, Y. J. Huang, L. N. Cleemann, N. J. Bjerrum, W. Xing, Appl. Catal. B, 2014, 144, 112-120.

[76] M. Chiwata, K. Kakinuma, M. Wakisaka, M. Uchida, S. Deki, M. Watanabe, H. Uchida, Catalysts, 2015, 5, 966-980.

[77] Y. Zhang, J. B. Zang, L. Dong, X. Z. Cheng, Y. L. Zhao, Y. H. Wang, J. Mater. Chem. A, 2014, 2, 10146-10153.

[78] C. K. Poh, S. H. Lim, Z. Q. Tian, L. F. Lai, Y. P. Feng, Z. X. Shen, J. Y. Lin, Nano Energy, 2013, 2, 28-39.

[79] S. B. Yin, M. Cai, C. X. Wang, P. K. Shen, Energy Environ. Sci, 2011 $4,558-563$

[80] W. M. Zhu, A. Ignaszak, C. J. Song, R. Baker, R. Hui, J. J. Zhang, F. H. Nan, G. Botton, S. Y. Ye, S. Campbell, Electrochim. Acta, 2012, 61, 198-206.

[81] A. C. Garcia, E. A. Ticianelli, Electrochim. Acta, 2013, 106, 453-459.

[82] M. K. Jeon, K. R. Lee, W. S. Lee, H. Daimon, A. Nakahara, S. I. Woo, J. Power Sources, 2008, 185, 927-931.

[83] B. C. Steele, A. Heinzel, Nature, 2001, 414, 345-352.

[84] P. Serp, M. Corrias, P. Kalck, Appl. Catal. A, 2003, 253, 337-358.

[85] R. Borup, J. Meyers, B. Pivovar, Y. S. Kim, R. Mukundan, N. Garland, D. Myers, M. Wilson, F. Garzon, D. Wood, P. Zelenay, K. More, K. Stroh, T. Zawodzinski, J. Boncella, J. E. McGrath, M. Inaba, K. Miyatake, M. Hori, K. Ota, Z. Ogumi, S. Miyata, A. Nishikata, Z. Siroma, Y. Uchimoto, K. Yasuda, K. Kimijima, N. Iwashita, Chem. Rev., 2007, 107, 3904-3951.

[86] Y. Y. Shao, J. Liu, Y. Wang, Y. H. Lin, J. Mater. Chem., 2009, 19, 46-59.

[87] E. Antolini, Appl. Catal. B, 2009, 88, 1-24.

[88] E. Antolini, Appl. Catal. B, 2010, 100, 413-426.

[89] Y. J. Wang, D. P. Wilkinson, J. Zhang, Chem. Rev., 2011, 111, 7625-7651.

[90] M. Pumera, Chem. Soc. Rev., 2010, 39, 4146-4157.

[91] A. Rabis, P. Rodriguez, T. J. Schmidt, ACS Catal., 2012, 2, 864-890.

[92] J. Tang, J. Liu, N. L. Torad, T. Kimura, Y. Yamauchi, Nano Today, 2014, 9, 305-323.

[93] Y. Y. Shao, Y. W. Cheng, W. T. Duan, W. Wang, Y. H. Lin, Y. Wang, J. Liu, ACS Catal., 2015, 5, 7288-7298.

[94] Y. Xiang, S. F. Lu, S. P. Jiang, Chem. Soc. Rev., 2012, 41, 7291-7321.

[95] Q. Zhao, Q. F. An, Y. Ji, J. W. Qian, C. J. Gao, J. Membr. Sci., 2011, $379,19-45$.

[96] M. Oezaslan, F. Hasché, P. Strasser, J. Phys. Chem. Lett., 2013, 4 3273-3291.

[97] Y. Nie, L. Li, Z. D. Wei, Chem. Soc. Rev., 2015, 44, 2168-2201.

[98] I. E. L. Stephens, A. S. Bondarenko, U. Grønbjerg, J. Rossmeisl, I. Chorkendorff, Energy Environ. Sci, 2012, 5, 6744-6762.

[99] A. Morozan, B. Jousselme, S. Palacin, Energy Environ. Sci., 2011, 4, 1238-1254.

[100] L. Du, Y. Y. Shao, J. M. Sun, G. P. Yin, J. Liu, Y. Wang, Nano Energy, 2016, DOI: 10.1016/j.nanoen.2016.03.016.
[101] M. Arenz, A. Zana, Nano Energy, 2016, D0I: 10.1016/ j.nanoen.2016.04.027.

[102] H. Lv, D. Li, D. Strmcnik, A. P. Paulikas, N. M. Markovic, V. R. Stamenkovic, Nano Energy, 2016, DOI: 10.1016/j.nanoen. 2016.04.008.

[103] S. Cherevko, N. Kulyk, K. J. J. Mayrhofer, Nano Energy, 2016, DOI: 10.1016/j.nanoen.2016.03.005.

[104] M. H. Shao, Q. W. Chang, J. P. Dodelet, R. Chenitz, Chem. Rev., 2016, 116, 3594-3657.

[105] M. Zhou, H. L. Wang, S. Guo, Chem. Soc. Rev., 2016, 45, 1273-1307.

[106] L. Du, S. Zhang, G. Y. Chen, G. P. Yin, C. Y. Du, Q. Tan, Y. R. Sun, Y. T. Qu, Y. Z. Gao, ACS Appl. Mater. Interfaces, 2014, 6, 14043-14049.

[107] Y. Takasu, N. Ohashi, X. G. Zhang, Y. Murakami, H. Minagawa, S. Sato, K. Yahikozawa, Electrochim. Acta, 1996, 41, 2595-2600.

[108] S. Mukerjee, J. Appl. Electrochem., 1990, 20, 537-548.

[109] F. Wen, U. Simon, Chem. Mater., 2007, 19, 3370-3372.

[110] S. P. Jiang, Z. C. Liu, H. L. Tang, M. Pan, Electrochim. Acta, 2006, 51, 5721-5730.

[111] Z. Q. Tian, S. P. Jiang, Z. C. Liu, L. Li, Electrochem. Commun., 2007, 9, 1613-1618.

[112] C. Bock, C. Paquet, M. Couillard, G. A. Botton, B. R. MacDougall, J. Am. Chem. Soc., 2004, 126, 8028-8037.

[113] Z. G. Estephan, L. Alawieh, L. I. Halaoui, J. Phys. Chem. C, 2007, 111, 8060-8068.

[114] H. J. Chen, Y. L. Wang, S. J. Dong, Inorg. Chem., 2007, 46, 10587-10593

[115] S. Zhang, Y. Y. Shao, G. P. Yin, Y. H. Lin, J. Mater. Chem., 2009, 19, 7995-8001.

[116] S. Zhang, Y. Y. Shao, H. G. Liao, J. Liu, I. A. Aksay, G. P. Yin, Y. H. Lin, Chem. Mater., 2011, 23, 1079-1081.

[117] T. Yu, D. Y. Kim, H. Zhang, Y. N. Xia, Angew. Chem. Int. Ed., 2011, $50,2773-2777$.

[118] Z. W. Quan, Y. X. Wang, J. Y. Fang, Acc. Chem. Res., 2012, 46, 191-202.

[119] N. Tian, Z. Y. Zhou, S. G. Sun, Y. Ding, Z. L. Wang, Science, 2007, 316, 732-735.

[120] A. M. Gómez-Marín, J. M. Feliu, Electrochim. Acta, 2012, 82, 558-569.

[121] J. Zhang, H. Z. Yang, J. Y. Fang, S. Z. Zou, Nano Lett., 2010, 10, 638-644.

[122] J. Chen, B. Lim, E. P. Lee, Y. N. Xia, Nano Today, 2009, 4, 81-95.

[123] T. S. Ahmadi, Z. L. Wang, T. C. Green, A. Henglein, M. A. El-Sayed, Science, 1996, 272, 1924-1926.

[124] N. Dahal, S. Garcia, J. P. Zhou, S. M. Humphrey, ACS Nano, 2012, 6, 9433-9446.

[125] C. K. Tsung, J. N. Kuhn, W. Y. Huang, C. Aliaga, L. I. Hung, G. A. Somorjai, P. D. Yang, J. Am. Chem. Soc., 2009, 131, 5816-5822.

[126] H. Song, F. Kim, S. Connor, G. A. Somorjai, P. D. Yang, J. Phys. Chem. B, 2005, 109, 188-193.

[127] R. Narayanan, M. A. El-Sayed, J. Phys. Chem. B, 2004, 108, 5726-5733.

[128] M. Miyake, K. Miyabayashi, Catal. Surv. Asia, 2011, 16, 1-13.

[129] M. Cao, K. Miyabayashi, Z. R. Shen, K. Ebitani, M. Miyake, J. Nanopart. Res., 2011, 13, 5147-5156.

[130] V. L. Nguyen, D. C. Nguyen, T. Hayakawa, T. Matsubara, M. Ohtaki, M. Nogami, J. Exp. Nanosci., 2012, 7, 133-149.

[131] M. E. Grass, Y. Yue, S. E. Habas, R. M. Rioux, C. I. Teall, P. D. Yang G. A. Somorjai, J. Phys. Chem. C, 2008, 112, 4797-4804.

[132] T. Herricks, J. Y. Chen, Y. N. Xia, Nano Lett., 2004, 4, 2367-2371.

[133] J. Y. Chen, T. Herricks, Y. N. Xia, Angew. Chem., 2005, 117, 2645-2648. 
[134] C. Kim, S. S. Kim, S. Yang, J. W. Han, H. Lee, Chem. Commun., 2012, 6396-6398.

[135] C. Wang, H. Daimon, Y. Lee, J. Kim, S. Sun, J. Am. Chem. Soc., 2007, 129, 6974-6975.

[136] C. Wang, H. Daimon, T. Onodera, T. Koda, S. Sun, Angew. Chem. 2008, 120, 3644-3647.

[137] R. Loukrakpam, P. Chang, J. Luo, B. Fang, D. Mott, I. T. Bae, H. R. Naslund, M. H. Engelhard, C. J. Zhong, Chem. Commun., 2010, 46, 7184-7186.

[138] Y. Kang, M. Li, Y. Cai, M. Cargnello, R. E. Diaz, T. R. Gordon, N. L. Wieder, R. R. Adzic, R. J. Gorte, E. A. Stach, C. B. Murray, J. Am. Chem. Soc., 2013, 135, 2741-2747.

[139] Y. Kang, J. B. Pyo, X. Ye, R. E. Diaz, T. R. Gordon, E. A. Stach, C. B. Murray, ACS Nano, 2013, 7, 645-653.

[140] S. I. Lim, I. Ojea-Jimenez, M. Varon, E. Casals, J. Arbiol, V. Puntes, Nano Lett., 2010, 10, 964-973.

[141] S. I. Lim, M. Varón, I. Ojea-Jiménez, J. Arbiol, V. Puntes, Chem. Mater., 2010, 22, 4495-4504.

[142] S. Zhang, Y. Y. Shao, G. P. Yin, Y. H. Lin, Angew. Chem., Int. Ed., 2010, 49, 2211-2214.

[143] X. Zhang, H. Wang, Z. H. Su, Langmuir, 2012, 28, 15705-15712.

[144] S. Y. Wang, X. Wang, S. P. Jiang, Nanotechnology, 2008, 19, 455602.

[145] D. G. Li, C. Wang, D. Tripkovic, S. H. Sun, N. M. Markovic, V. R. Stamenkovic, ACS Catal., 2012, 1358-1362.

[146] Q. Li, L. H. Wu, G. Wu, D. Su, H. F. Lv, S. Zhang, W. L. Zhu, A. Casimir, H. Y. Zhu, A. Mendoza-Garcia, S. H. Sun, Nano Lett., 2015, 15, 2468-2473.

[147] S. Y. Wang, S. P. Jiang, X. Wang, Nanotechnology, 2008, 19, 265601.

[148] M. Amatatongchai, W. Sroysee, S. Chairam, D. Nacapricha, Talanta, 2015, 133, 134-141.

[149] D. Bin, F. F. Ren, Y. Wang, C. Y. Zhai, C. Q. Wang, J. Guo, P. Yang, Y. K. Du, Chem. Asian J., 2015, 10, 667-673.

[150] Y. F. Fan, Y. C. Zhao, D. H. Chen, X. Wang, X. L. Peng, J. N. Tian, Int. J. Hydrogen Energy, 2015, 40, 322-329.

[151] P. Kaur, M. S. Shin, S. R. Chae, M. S. Kang, J. S. Park, S. Singh Sekhon, J. Phys. Chem. Solids, 2015, 85, 155-159.

[152] S. B. Zhang, Y. M. Shen, G. Y. Shen, S. Wang, G. L. Shen, R. Q. Yu, Anal. Biochem., 2016, 494, 10-15.

[153] J. W. Kim, J. H. Heo, S. J. Hwang, S. J. Yoo, J. H. Jang, J. S. Ha, S. Jang, T. H. Lim, S. W. Nam, S. K. Kim, Int. J. Hydrogen Energy, 2011, 36, 12088-12095.

[154] Y. Lin, S. C. Zhang, S. H. Yan, G. R. Liu, Electrochim. Acta, 2012, 66, $1-6$.

[155] T. T. Nguyen, V. T. T. Ho, C. J. Pan, J. Y. Liu, H. L. Chou, J. Rick, W. N. Su, B. J. Hwang, Appl. Catal. B, 2014, 154, 183-189.

[156] S. J. Guo, S. J. Dong, E. Wang, ACS Nano, 2010, 4, 547-555.

[157] B. M. Luo, S. Xu, X. B. Yan, Q. J. Xue, J. Electrochem. Soc., 2013, 160,
F262-F268.

[158] S. Y. Wang, D. S. Yu, L. M. Dai, J. Am. Chem. Soc., 2011, 133, 5182-5185.

[159] S. Y. Wang, D. S. Yu, L. M. Dai, D. W. Chang, J. B. Baek, ACS Nano, 2011, 5, 6202-6209.

[160] M. Pan, H. L. Tang, S. P. Jiang, Z. C. Liu, J. Electrochem. Soc., 2005, 152, A1081-A1088.

[161] S. P. Jiang, Z. C. Liu, Z. Q. Tian, Adv. Mater., 2006, 18, 1068-1072.

[162] M. Yang, S. F. Lu, J. L. Lu, S. P. Jiang, Y. Xiang, Chem. Commun., 2010, 46, 1434-1436.

[163] S. P. Jiang, H. L. Tang, Colloids Surf., A, 2012, 407, 49-57.

[164] K. de O. Santos, W. C. Elias, A. M. Signori, F. C. Giacomelli, H. Yang, J. B. Domingos, J. Phys. Chem. C, 2012, 116, 4594-4604.

[165] Y. X. Lu, L. Liu, W. Foo, S. Magdassi, D. Mandler, P. S. Lee, J. Mater. Chem. C, 2013, 1, 3651.

[166] X. L. Liu, Y. F. Gao, R. H. Jin, H. J. Luo, P. Peng, Y. Liu, Nano Energy, 2014, 4, 31-38.

[167] D. H. Li, J. F. Wehrung, Y. Zhao, J. Mater. Chem. A, 2015, 3, 5176-5182.

[168] G. Q. Guo, F. Qin, D. Yang, C. C. Wang, H. L. Xu, S. Yang, Chem. Mater., 2008, 20, 2291-2297.

[169] S. Brimaud, S. Pronier, C. Coutanceau, J. M. Léger, Electrochem. Commun., 2008, 10, 1703-1707.

[170] F. Qin, W. Shen, C. C. Wang, H. L. Xu, Catal. Commun., 2008, 9, 2095-2098.

[171] G. R. Xu, S. H. Han, Z. H. Liu, Y. Chen, J. Power Sources, 2016, 306, 587-592.

[172] C. Arbizzani, M. Biso, E. Manferrari, M. Mastragostino, J. Power Sources, 2008, 180, 41-45.

[173] L. M. Huang, T. C. Wen, J. Power Sources, 2008, 182, 32-38.

[174] C. W. Kuo, C. Sivakumar, T. C. Wen, J. Power Sources, 2008, 185, 807-814.

[175] S. Y. Wang, F. Yang, S. P. Jiang, S. L. Chen, X. Wang, Electrochem. Commun., 2010, 12, 1646-1649.

[176] W. Yang, Y. Wang, J. Li, X. R. Yang, Energy Environ. Sci., 2010, 3, 144-149.

[177] S. Mayavan, H. S. Jang, M. J. Lee, S. H. Choi, S. M. Choi, J. Mater. Chem. A, 2013, 1, 3489-3494.

[178] Z. Y. Guo, C. C. Jiang, C. Teng, G. Y. Ren, Y. Zhu, L. Jiang, ACS Appl. Mater. Interfaces, 2014, 6, 21454-21460.

[179] L. Q. Jiang, L. L. Cui, X. Q. He, J. Solid State Electrochem., 2014, 19, 497-506.

[180] F. P. Pan, S. Guo, J. Y. Zhang, Electrochimica Acta, 2015, 180, 29-36.

[181] D. K. Park, S. J. Lee, J. H. Lee, M. Y. Choi, S. W. Han, Chem. Phys. Lett., 2010, 484, 254-257.

[182] K. Ahn, M. Kim, K. Kim, H. Ju, I. Oh, J. Kim, J. Power Sources, 2015, 276, 309-319.

\title{
聚电解质聚二烯丙基二甲基氯化铵在高分子膜燃料电池中的应用: 从纳米颗粒到载体材料
}

\author{
杜 否 ${ }^{\mathrm{a}, \mathrm{b}}$, 孔凡鹏, 陈广宇 ${ }^{\mathrm{b}}$, 杜春雨 ${ }^{\mathrm{b}}$, 高云智 ${ }^{\mathrm{b}}$, 尹鸽平 ${ }^{\mathrm{a}, \mathrm{b}, *}$ \\ 哈尔滨工业大学, 化工与化学学院, 城市水资源与水环境国家重点实验室, 黑龙江哈尔滨 150090 \\ 哈尔滨工业大学, 化工与化学学院, 特种电源研究所, 黑龙江哈尔滨 150001
}

摘要: 高分子膜燃料电池是一类很有发展前景的可提供可再生能源的装置, 这主要得益于它的零排放、无毒性和较低的操 作温度. 在高分子膜燃料电池的部件中, 电催化剂对于提高输出能量密度和/或工作寿命起到至关重要的作用. 在过去的 
几十年中, 科学家提出了很多办法和策略以解决电催化剂的活性和稳定性问题. 尽管基于聚电解质的层层自组装制备膜 电极的方法已经研究多年, 但聚电解质在催化剂制备方面的作用仍需更多的关注. 最近几年, 已有很多人将聚电解质应用 于催化剂设计制备, 其中聚二烯丙基二甲基氯化铵(PDDA) 的研究较为系统, 因此, 本文重点关注 PDDA, 目的是总结出一些 有用的信息, 以便为该领域未来的研究发展提供一些参考.

本文收集了一些聚电解质在电催化剂纳米颗粒和载体材料两方面应用的文献, 不仅讨论了聚电解质在催化剂颗粒粒 径、形貌和组成方面的影响, 还总结了其在修饰载体材料方面的应用. 最后, 本文还展望了聚电解质在催化剂设计制备领 域的发展. 通常, 聚电解质有三个主要的特征: (1) 在水溶液中容易解离为带相反电荷的长链结构和离子; (2) 长链结构中 带有独特的官能团结构; (3) 当溶液浓度变化时其结构会发生转变. 因此, 聚电解质可以在电催化剂层面作为纳米反应器 来控制金属纳米颗粒的生长, 可功能化或掺杂纳米颗粒以及载体材料, 可以保护纳米颗粒或载体不衰减, 同时还可使其他 物质带电, 利用自组装方法制备有序的催化剂. 然而, 相关研究大都集中于 PDDA, 因此, 其他聚电解质还需要进一步的系 统研究, 以便了解聚电解质特征、制备的催化剂以及催化性能之间的关系.

PDDA 在该领域的研究还需在如下几个方面继续进行. (1) 聚电解质通常不是电子的良导体, 其在催化剂表面的吸附 会造成活性位的损失. 尽管已经提出一些相对有效的方法, 例如热处理、化学洗涤或光降解等, 但仍需继续进行系统的研 究和提出有效的方法. (2) 先进的研究手段, 如原位观测和模拟等还需进一步发展, 尤其是研究聚电解质在催化剂形成过程 中的功能和影响, 这有利于构效关系的研究. (3) 目前该领域制备的催化剂大都使用半电池或三电极体系来评价, 但与实际 的燃料电池装置有本质不同. 由于复杂的工作条件, 例如水热管理、不同组件的界面耦合等, 聚电解质制备催化剂在膜电 极中有可能不能表现出优良的性能. 因此, 上述催化剂的研究还应考虑燃料电池的实际运行情况.

关键词: 聚电解质; 纳米颗粒; 载体; 可控合成; 功能化

收稿日期: 2016-03-11. 接受日期: 2016-04-26. 出版日期: 2016-07-05.

*通讯联系人. 电话/传真: (0451)86403807; 电子信箱: yingeping@hit.edu.cn

基金来源：国家自然科学基金 (21276058, 21433003); 城市水资源与水环境国家重点实验室自主课题 (2014DX10); 中国国家留学 基金委.

本文的英文电子版由Elsevier出版社在ScienceDirect上出版(http://www.sciencedirect.com/science/journal/18722067). 